\title{
Rehabilitation and Creation of Favorable Conditions for the Improvement of the Comfort and Quality of Acrylates Used in the Sphere of Removable Dentures
}

\begin{abstract}
RAMONA DIANA FEIER ${ }^{1}$, GABI TOPOR ${ }^{2}$, LUCRETIA ANGHEL2*, ANDRA ELENA AUNGURENCE ${ }^{3 *}$, MAGDALENA RUSU NEGRAIA²
'Dimitrie Cantemir University, Faculty of Medicine and Pharmacy, 3-5 Bodoni Sandor Str., Targu Mures, Romania 2Dunarea de Jos University of Galati, Faculty of Medicine and Pharmacy, 47 Domneasca Str., 800008, Galati, Romania ${ }^{3}$ Grigore T. Popa University of Mediicine and Pharmacy, Faculty of Dental Medicine, 16 Universitatii str., 700115, Iasi, Romania

The total acrylic denture is a conventional prosthesis method in case of total edentation, when there are 12 remaining teeth on the arch. The purpose of these dentures is to recreate functionality and improve the esthetic condition, being the optimum solution for improving the life of patients who have lost their natural teeth. Acrylic resins have been used in dentistry since 1937, a date which marked the progressive and final replacement of vulcanized rubber (vulcanite). From a chemical point of view, acrylates are macromolecular resins derived from acrylic acid, obtained by polymerization of several substances which derive from the acrylic acid, methacrylic acid and the esters of these acids. Metallic inserts can be added in the structure of the plastic masses, under the form of wires, bars, grids, nets. Bar and wire reinforcement has been proved efficient in improving the mechanical properties of the bases of total dentures, compared to grids, which failed to constantly ensure significant improvement. The position and thickness of reinforcement inside the plastic mass hugely influences the efficiency of reinforcement; the reinforcement must be placed perpendicularly on the anticipated fracture line. Our study was carried out in the Dental Clinic and comprises a number of 17 patients. The lot included patients aged between 50 and 85. Clinical observations have been made on fracture cases of acrylic bases, followed by the analysis and assessment of certain clinical aspects with a high risk of fracture (maxillary/mandible, with a median/paramedian line, etc.) which, associated, increase the risk of fracture even more. Clinical observations have shown the presence of fracture risk in acrylic dentures, showing the necessity of a correct design and production of removable dentures butalso of using inserts.
\end{abstract}

Keywords:acrylic prostheses, metallic inserts, polymers, reinforcement, plastics.

In 1843, the methacrylic acid was discovered. Caspary and Tollens managed to obtain, in 1873, the first acrylic plastics; in 1924 they were synthesized for the first time and in 1935 their use extended to the dental technique. These resins have witnessed multiple improvements, reaching a large variety in the present and they can still be potentially improved.

In dentistry polymerized methyl methacrylic products are used, under the name of metal polymethacrylate or PMMA, according to the FDI specifications.

Acrylic resins have dominated for decades the technology of dental prostheses, serving as a basis for removable dentures, artificial teeth, facets and even unidental prostheses (s) acket crowns, incrustations), immobilization tracks, etc.

Slowly, a series of deficiencies in these materials have been shown, especially when used for the production of artificial teeth, certain uni-dental prostheses and for plating purposes. The researches have followed two directions: on the one hand, new types of acrylic resins have been elaborated, with improved properties, mostly in the polymerizablemethacryloyloxy group (from methyl methacrylate) and, on the other hand, other polymers have been created: diacrylic, epoxydic, polycarbonate, epiminic resins, with the intention of substituting the deficiencies of acrylic resins[1-4].

One of the landmark events that busted the development of polymers for the production of dental prostheses was triggered by Bowen who, in the period from 1958 to 1962 , elaborated a new class of polymers based on aromatic dimethacrylate, which can also contain inorganic fillings (the bond between the two phases being ensured by a coupling agent), thus giving birth to composite diacrylic resins (RDC). These materials have taken acrylic resins out of the race in several fields of dental prostheses production, such as artificial teeth and plating materials.

At the moment, new types of non-composite, very compact resins have been introduced. They show higher density, high rigidity, hardness and resistance to wear, aiming at replacing even metallic alloys from certain dental prostheses: esthetic brackets, skeletal prostheses made exclusively of resins, orthogonal brackets, etc. Such a polymer is polyoxyethylene.

The weight of acrylic resins in dentistry is still high, as they are used for the production of fixed and removable denture bases, artificial teeth, temporary crowns, epitheses, etc.

Dentistry has been revolutionized by the discovery of macromolecular compounds. In their continuous and accelerated development, chemistry and the technology of macromolecular compounds have made available for dentistry new high-performance materials and techniques, which otherwise would have been impossible using classical means[5-7].

Synthetic polymersare equally used in the dental cabinet and in the dental technical laboratory. 
Auto and thermo-polymerizable acrylic resins are used for the production of fixed and removable denture bases; the repair and optimization of fixed and removable dentures; surgical prostheses - epitheses; artificial teeth, conformatures, gutters and gum prostheses; uni-dental prostheses and temporary bridges, orthodontic devices.

Composite diacrlyic resins (RDC) have superior properties, lowed contraction at polymerization, higher values of physical, mechanical, chemical and electrical resistance, better thermo-insulant and physical chemical features (uni-dental prostheses, dental bridges, plating materials, etc.).

Epiminicresisns, whose structure resembles epoxydic resins (the oxygen atom from the epoxydic cycle was replaced with the iminic -NH group) have a lower $n$ polycondensation degree. They are auto-polymerizable and are used for the production of certain temporary prostheses.

Polyamide resins, with good mechanical resistance but a low module of elasticity.

Polyamides or polymers resulting from the condensation of a diacid with a diamide, giving birth to a variety of reaction products whose physical and mechanical properties depend on the groups that reticulate acid or amine radicals.

The first type of nylon used for the production of teeth was a failure, since the type used absorbed water excessively, leading to a certain degree of plasticization and even biodegradation of the material. The introduction of glass-reinforced nylon showed promising results. This type of material is reinforced with glass particles or fibers, which ensures a higher rigidity compared to glass pearls, being close to the rigidity of the thermo-polymerizablePMMA[9-12].

One of the advantages of polyamide resins as prosthesis materials was their good mechanical bending resistance but soon the disadvantages of these resins surfaced: low module of elasticity; limited ability to preserve shape and volume; evident chromatic modifications; poor ability of fixation and preservation of teeth and brackets; their manipulation and technology requires complicated equipment.

Polycarbonate resins are condensation derivates of carbonic acid, with a dense structure and superior physical and mechanical properties compared to acrylic resins; they are processed by injection and used for the industrial production of certain temporary crowns.

Polyoxymethylene resins or acetal homopolymers, are obtained following the polymerization of formaldehyde and are recommended for partial brackets, temporary crowns and bridges, artificial teeth, orthodontic devices, skeletal prostheses, partial prostheses, total prostheses, etc.

At the moment, the properties of the polymers used for the production of total or partial prostheses bases have been improved in at least three directions: ensuring a radioopacity of the material; increase of the impact resistance; increase of rigidity[13-16].

Photopolymerizable diacrylic resins - the weight of diacrylic resins in the production of dental prostheses has increased spectacularly, especially with regard to uni-dental prostheses: inlays, mixed crowns, on-lays, jacket crowns or temporary bridges (crowns). The origin of these materials is closely connected to the name of doctor Castang who, in 1936, synthesized an epoxydic resin, out of which he intended to manufacture artificial teeth.

Epoxydic resins constituted the starting point for the creation of the most important polymers used in the dental practice of our century, composite diacrylic resins.
After Dr. Castang's failure, the first breakthrough in the field belongs to Bowen who, between 1957 and 1962 when he used to work for the US National Bureau of Standards, discovers a monomer based on which several types of diacrylic resins have been subsequently synthesized[1719].

Diacrylic resins show lower contraction to polymerization, low thermal dilatation; low water absorption (between $0.13 \%$ and $1.7 \%$, compared to $2 \%$ for PMMA), higher mechanical performance (bending and compression resistance, etc.) compared to PMMA, the possibility of physical and chemical adhesion to the metallic skeleton, while the bond between PMMA and metal is only macro-mechanical, low aging phenomena, better physiognomic effects compared to the PMMA and relatively good long term chromatic stability[20-23].

From a chemical point of view, the organic matrix is a dimethylacrylate urethane reinforced with pyrolytic silica, acrylate pearls and acrylic resins monomers with high molecular mass.

Metallic inserts:as early as the 60 's, orthodontic devices would be reinforced with nets, wire or plates of stainless steel. A unique and thick reinforcement provides resistance and rigidity, but the discontinuity it produces in the relief of the denture is uncomfortable and unwanted. That is why two or several reinforcements are preferred, of small thickness and placed several millimeters apart.

The low adhesion between the metallic particles and the polymer is the main problem at the basis of countless failures to reinforce acrylates. In view of improving this adhesion, various techniques of conditioning metallic particles have been promoted, such as sandblasting, silanization, the use of various adhesive resins. The rugosity thus obtained has a beneficial effect on the parts' fracture resistance[24-26].

The best results were obtained following sand-blasting, the retention between the reinforcement and the resin being improved by the increase of interference between the two materials. The use of a 4-Meta type adhesive also yielded positive results to increase adhesion between inserts and resins. Another method of conditioning metallic inserts is silanization, its efficiency being proved by the increase of fracture resistance of the acrylate - metal structure.

Kevlar fibers have very high rigidity - 90Cpa, are light yellow, light and very resistant. The reinforcement of polymers (PMMA and Bis-GMA based polymers) using these fibers leads to a spectacular increase of mechanical properties. Because they provide a less esthetic aspect, their use is limited to the oral faces of artificial teeth and total prostheses[27-30].

Carbon fibers give composite materials high resistance to fracture and significant rigidity. The construction ofthe denture base with carbon fibers requires a longer working time compared to PMMA, classic prostheses. The presence of the carbon fiber reinforcement considerably increases stress and flexion resistance (by more than $70 \%$ ) and the torsion resistance (by more than $50 \%$ ).

The results of experiments confirm the significant improvement of the mechanical properties of resins after having been reinforced with carbon fibers.

Perma Fiberare revolutionary glass fibers, due to the fact that each fiber is impregnated, by means of computer, with acrylic resin (porous polymer) and silane, which allows the creation of a strong bond with all acrylic resins. Glass fibers are recommended for a simple technique, with multiple use possibilities, that leads to composite materials with higher physical characteristics compared to simple acrylates. 
The proper adhesion of fibers to the polymer matrix is the most important factor in obtaining an increased hardness. The creation of this bond requires a proper impregnation of the fibers; with this bond, a smooth surface can be obtained following polishing, thus eliminating the possibility of tissue irritation[31-33].

Materials that create a chemical bond show a hardness that is 100 times higher than materials without reinforcement. That is due to the elimination of voids between the acrylic resin and the inserts. Polyethylene, Kevlar fibers, metal mashes fail to create such a good bond with acrylic resins[34-37].

Proper adhesion to the polymer matrix of the fibers is the most important factor in obtaining hardness. The creation of bond requires a proper moisturizing of fibers.

There are polyethylene fibers, vinyl polymers made of ethylene, that may have a branched or linear structure. Linear structure fibers have a higher degree of pliability and hardness than branched ones and, due to the denser structure, show higher resistance to forces.

Ribbond fibers prevent fractures in composite works and in acrylic resins and the prostheses maintain the same initial properties for a longer time. The unique combination of Ribond fibers creates a very good bond and their structure increases the fracture resistance and hardness of the prostheses. These fibers are made of polyethylene fibers[38-40].

Total prostheses offer multiple benefits: the patients can chew much better diverse foods, pronunciation is improved and the denture also provides support for the lips and the cheeks, thus eliminating the sinking aging effect of edentulous patients, maintaining the health of the gums and maxillary[41-43].

The data base was managed by means of Excel from the Microsoft Office package and the statistical analysis benefited from the statistically dedicated softwareMedCalcandEpi Info 2000.

The statistical software used represents an environment for solving problems using mathematic statistics methods and techniques through the processing of data obtained through measurement and the realization of proper graphic representations, a dedicated software for the statistical data processing, the results yielding clear conclusions on the phenomena under investigation [44-46].

\section{Experimental part}

\section{Material and methods}

Our study was carried out in the Dental Clinic and comprises a number of 17 patients. The lot included patients aged between 50 and 85 . They included 1 male and 5 females aged 55-64, 4 males and 2 females aged 65-74 and 3 males and 2 females in the last age group, 7585(Fig.1).

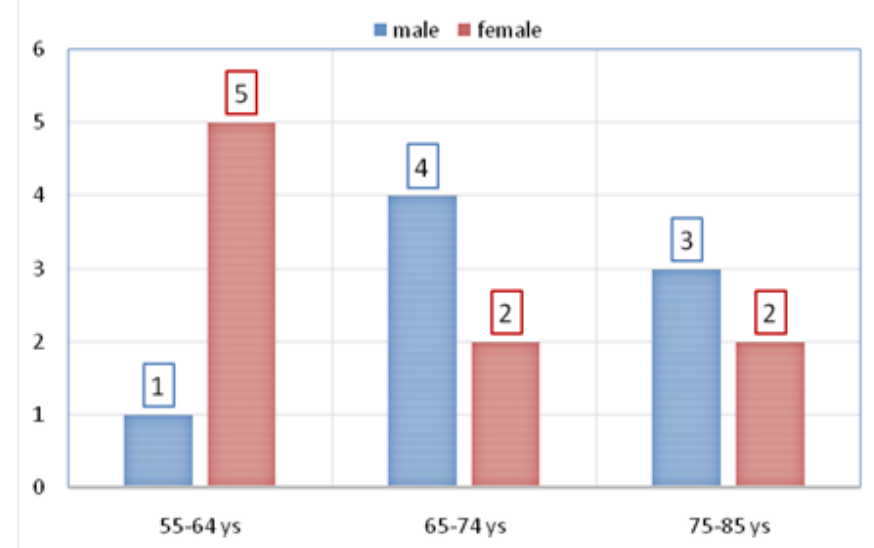

\section{Results and discussions}

The study aimed at improving the quality of acrylates used in the sphere of removable dentures. We excluded from the study those who were not willing to participate to the study for the entire period; non-cooperant patients, patients with psychic affections that could influence their ability to understand and follow the treatment; patients with gastro-intestinal disorders, with a main manifestation in malabsorption, which count influence the results of the parenteral treatment.

Clinical observations were made on the cases of acrylic bases fractures, with the analysis and assessment of certain clinical aspects showing high fracture risk (maxillary/mandible, with a median/paramedian fracture line, etc.) which, in association, increase the risk of fracture even more. As alternative solutions we used glass fiber reinforcement, making observations on the technique used, clinical and technical advantages compared to metallic mash reinforcement.

O.F. patient, aged 56 , reported to the cabinet following a fracture of his prosthesis, the doctor's recommendation being a total maxillary reinforced denture with the base made of transparent acrylate, as the patient also had fractured in the past two prostheses and shows allergy to pink acrylate.

As the impressions fulfilled all requirements, we moved on to the following stage, the construction of the preliminary model. After placing the model in water for several minutes, we moved on to the stage of production the individual port-impression; using a chemical pen we delimited the lines of the prosthetic field, in vestibular plane to the cul-de-sac, bypassing the frenula, and in distal plane to the level of the Ah line. On the model that was isolated in water for several minutes we made the occlusion mold, mounting models in the articulator. We made the model of the prosthesis, the mold and polymerization of the prosthesis. After cooling we carried out dismantling, mechanical processing of the prosthesis and polishing.

Another case, following a prosthesis fracture which had suffered numerous repairs, B.C. patient, aged 57, reported to the dentist. The doctor's decision was to make a reinforced total mandible acrylic denture, with the base made of transparent acrylate, as the patient showed a very irritated mucous surface.

The clinical cases analyzed were treated by improving the classical treatment through the reinforcement of the prosthesis base by means of a metallic mash or glass fibers to increase the resistance of maxillary and mandibular prostheses when there is maxillary or mandibular torus which cannot be removed surgically due to the patient's poor general condition.

The total acrylic prosthesis is a treatment solution hard to accept, due to the large volume it takes in the oral cavity and the large surface of mucous membrane covered by the prosthesis base.

These deficiencies are shortly noticed after the insertion of the prosthesis and notified to the specialist under the form of discontent. The interventions for the reduction of the base to improve comfort, unveiling a part of the prosthetic field (windows, undercutting, cutting out) are proofs in the attempts of obtaining a prosthesis that is as good as possible. The intervention to reduce the base is followed by a decrease of the tearing resistance of the prosthesis under the action of occlusal forces, thus swapping one disadvantage for another. An increase mechanical resistance was obtained when the acrylic resin bases were replaced with metal inserts. This replacement led in turn to the creation of favorable conditions for comfort, 
the metal being resilient and the base being smaller in size. Thus reinforced prostheses were created, which can successfully replace both acrylic resin bases and metal bases. The variety of reinforcement procedures and techniques make this possible.

The modern orientations in the therapeutic approach of total edentation focus on implants, but the clinical reality, correlated with multiple social aspects show the limits related to the general condition.

\section{Conclusions}

Prostheses ensure the patients a higher quality of life, a better aspect and nutrition, better phonation, all with positive aspects. The look, the smile and facial expression are very important in communication and prostheses have an impact in today's society which exceeds common perception.

The clinical observation showed the presence of a fracture risk in acrylic prostheses, which led to the necessity to correctly design and produce removable dentures in the first place, but also to use inserts.

A denture that restores, improves aspect and ensures all functions is something the dentist, the technician but also the patient take pride in.

\section{References}

1.ACOSTA-TORRES LS.,BARCELO-SANTANA FH., ALVAREZ-GAYOSSO CAA., REYES-GASGA J. Synthesis and characterization of poly(methylmethacrylate) polymerized by microwave energy or conventional water bath.J .of Applied Polymers Science, 2008;109:39533960.

2.ANUSAVICE KJ. Phillips's Science of Dental Materials.11thEdition Philadelphia, PA. Saunders,2003.

3.AVON SL.,GOULET J P.,DESLAURIERS N. Removable acrylic resin disk as a sampling system for the study of denture biofilms in vivo. Journal of Prosthetic Dentistry, 2007;97(1):32-38.

4.AZZARRI MJ .,CORTIZO MS.,ALESSANDRINI JL. Effect of the curing conditions on the properties of an acrylic denture base resin microwave-polymerised. J.ofDentistry ,2003;31(7): 463-468.

5.BARBOSA DB.,BARAOVA.,MONTEIRO DR. et al. Bond strength of denture teeth to acrylic resin: effect of thermocycling and polymerisation methods.Gerodontology,2008; 25(4):237-244.

6. BARBOSA DB.,SOUZA RF., PERO AC. et al. Flexural strength of acrylic resins polymerized by different cycles. J Appl Oral Sci.2007;15:424-428.

7.BAYRAKTAR G.,GUVENER B.,BURAL C. et al. Influence of polymerization method, curing process, and length of time of storage in water on the residual methyl methacrylate content in dental acrilicresins.J . of Biomedical Materials Research, 2006;76B(2):340345.

8.BETTENCOURT AF.,NEVES CB., de ALMEIDA M.et al.Biodegradation of acrylic based resins:Areview.Dental Materials, 2010;26(5):171-180. 9.BONNATIMR.,CUNHATR.,REGIS RR. et al. The effect of polymerization cycles on color stability of microwave-processed denture base resin.J. of Prosthodont,2009;18:432-437.

10.BRATU D., IEREMIA L., TUCULESCU S., Bazele clinice si tehnice ale protezarii edentatiei totale, Editura Imprimeriei de Vest, Oradea, 2003.

11.BURLUI V, MIHAELA SILIVAS, Clinica si terapia edentatiei totale, Editura Apollonia, lasi 2003.

12.BUYUKERKMEN B.,OZTURKA., Effect of polymerisation techniques on residual monomer amount released from different acrylic resins.MaterialsResearchs Innovations, 2010;14(5):381-384.

13.MIRCEA SUCIU, FLORENTIN BERNEANU, DIANA CERGHIZAN: Aspecteclinico-tehnice ale tratamentului edentatiei partiale prin proteze mobilizabile, Litografia UMF Tg. Mures, 2006.
14.MIRCEA SUCIU: Aspecteclinico-tehnice ale edentatiei totale bimaxilare, Litografia UMF Tg. Mures, 2004.

15.CIURCANU O.E, FORNA, D.A., POPA C., SCUTARIU M.M. Implementation of methods of loco-regional anesthesia in dental surgery, Romanian journal of oral rehabilitation, Vol. 9, Issue: 4, 2017. Pg. 120-127

16.SCUTARIU M.M., CIUPILAN C., SALCEANU M., MELIAN A., FORNA D.A, SIOUSTIS I., CIURCANU O.E., Incidence of dento-periodontal pathology in geriatric patients, Romanian journal of oral rehabilitation, Vol. 10 (1), 2018. Pg. 128-132

17.NEUMANN C., Tehnologia protezelor dentare partiale adjuncte, Editura J unimea, lasi, 2000.

18.ROMINU MIHAI, Polimerizarea in stomatologie,EdituraBrumar, Timi-oara 2000.

19.SORIN POPSOR, MIRCEA SUCIU: Principii esentiale de protezare fixa, Litografia UMF Tg. Mures, 2006.

20.VITALARU ANCA MIHAELA, Tehnologia protezei totale. Aspecte practice. Editura Performatica, lasi, 2006.

21. NICULESCU, O., NICA, P., GURLUI, S.,et al., Experimental investigations of polymer plasma laser ablation, Mat.Plast., 46, no.3, 2009, pg.336-338

22.GRADINARU, I., IGNAT, L., DASCALU, C.G., SOROAGA, L.V., ANTOHE,M.E., Studies regarding the architectural design of various composites and nanofibres used in dental medicine, Rev.Chim.(Bucharest),69, no.2, 2018, p.328-331

23. VASLUIANU, E., POPESCU,V., GRIGORIU, A., et al., Comparative study concening the FIR Analysis and the performances of chitosan based wrinkle-proofing agents, Rev.Chim.(Bucharest),64, no.10, 2013, p.1104-1115

24.ANTOHE, M.E.,DASCALU,C., SAVIN,C.,FORNA,N.C., BALAN, A., Study Regarding the Toxic Effects of Acrylic Resins,Mat.Plast., 53, no.4, 2016, 767-770

25.BARLEAN, L.M., AUNGURENCEI, A., AUNGURENCEI, O. SCUTARIU, M.M., BALCOS, C., MOISEI, M.., Latex Glove Allergy Among Dentists in Iasi, Romania, Rev.Chim.(Bucharest),66, no.11, 2015, pg. 18771880

26. NASH,D.,RUOTOISTENMAKI,J ., ARGENTIERI,A.et al.,Profil of the oral healhcare team in countries with emerging economies, Conference Global Congress on Dental Education location,Dublin,Ireland, European J ournal of Dental Education,12((1), 2008, pg.111-119

27.GRADINARU, I., IGNAT, L., ANTOHE, M.E., HURJUI,L.L., Biomaterials used in oral rehabilitation of the edentulous allergic patients, Romanian J ournal of Oral Rehabilitation,Vol.10,No.1,pg.114-119,2018

28.POPESCU,V., VASLUIANU,E., FORNA,N.C., et al., Comparative study of the FTIR Analysis and the peformances of N,N,N-trimethyl chitosan as wrinke-poofing agent, Rev.Chim.(Bucharest),64, no.11,2013, pg.1284-1294

29.GRADINARU,I.,DASCALU,C.G.,ANTOHE, M.E.,Esthetic landmarks in different types of prostheses correlated with the biomaterials structure,E-Health and Bioengineering Conference (EHB), 2017, 647650

30. BELEI, D., FORNA, N.C.,SANDU, I., etal.,NovelMesoionic 2-Methyl14-(1,3-Dithiol-2-yllum) phenolates, Rev.Chim.(Bucharest),65, no.,2014,pg.80-83

31. ASAFTEI, I.V., EARAR, K., BIRSA, L.M. et al. Conversion of light hydrocarbons with butanes from petroleum refining processes over Zn-HZSM-5 and Zn 0/HZSM-5 catalysts, Rev.Chim.(Bucharest), 66, no.7, 2015,p.963-971

32. ANTOHE, M.E., AGOP FORNA, D., DASCALU, C.G., Implications of digital image processing in the paraclinical assessment of the partially edentated patient, Rev.Chim.(Bucharest), 69, no.2,2018 p.521-524

33.EARAR, K., ANTONIAC, V.I., BACIU, S., et al, Etching treatment effect on surface morphology of dental structures, Rev. Chim. (Bucharest), 68, no.11,2017, p.2700

34.ANCUTA ,C., POMIRLEANU, C., IORDACHE,C., et al., Serum lipid profile in diffuse versus limited systemic sclerosis data from the SASS cohort, Rev.Chim.(Bucharest), 69, no.2, 2018, p.403-406 
35.IORDACHE,C., GHIORGE,C.A., ANTOHE M.E., et al., Temporomandibular joint involvement in rheumatoid arthritis and ankylosing spondylitis:a cross-sectional study, 994,2017 ,pg.40-46

36.BARTOLO P., BIDANDA B., Biomaterials and prototyping applications in medicine, NewYork, Springer Science and Bussines Media, 2008. 37. ANTOHE,M.E., FORNA AGOP D., DASCALU,C.G., FORNA, N.C., The importance of observing the aesthetic requirements in partial edentulous rehabilitation-implications in medical-dental training, International journal of education and information technologies 10 , 199-203,2016

38. POPA , C., STELEA, C.G., FILIOREANU,A.M., et al., PCR Analysis of the Herpesviruses presence in crevicular fluid in HIV-positive patients, Rev.Chim.(Bucharest), 68, no.11, 2017, p.2672-2675

39.FORNA AGOP ,D., POPESCU, E., COSTAN V.V., et al.,Conventional maxillary reconstruction using service obturators, Romanian Journal of Oral rehabilitation, (8),3,2016, pg.32-39

40.HRISTIAN,L., BORDEIANU,D.L., IUREA, P., et al Study of the tensile properties of materials destined to manufacture protective clothing for firemen, Mat.Plast., 51, no.4, 2014, p.405-409

41.DASCALU, C.G., CARAUSU, E.M., MANUC, D., Methods for Data Selection in Medical Databases: The Binary Logistic Regression Relations with the Calculated Risks, Proceedings of world academy of science, engineering and technology, VOL 28 Book Series: Proceedings of World Academy of Science Engineering and Technology Volume: 28 Pages: 278-+ Published: 2008

42.J UMANCA, D., GALUSCAN, A., PODARIU, A.C., et al.,Antiinflammatory action of toothpastes conainingbetulinnanocapsules, Rev.Chim.(Bucharest), 65, no.12,2014, p.1473-1476

43.AYKENT F.,YONDEM Y.,OZYESIL G.et al. Effect of different finishing techniques for restorative materials on surface roughness and bacterial adhesion. J .ofProsth. Dentistry, 2010;4(103): 221-227.

44.SAVIN, C., ANTOHE, M.E., BALAN, A., et al., Study regarding the elastic impression biomaterials dimensional stability, Rev.Chim.(Bucharest), 70, no.3, 2019,p.797-800

45.VITALARIU, A.,TATARCIUC, M.,LUCA, O., HOLBAN CIOLOCA, C.,BULANCEA, B., AUNGURENCEI,A., AUNGURENCEI, O., RAFTU, G., DIACONU POPA, D., Structural and thermal changes in dental resins enriched with silver nanoparticles Rev.Chim.(Bucharest),70, no.2, 2019, p.591-595

46.DROCHIOI, C.,COSTAN V.V., ZAHARIA, M., et al.,FT-IR Characterization of some biological materials used in reconstructive surgery, Rev.Chim.(Bucharest), 66, no.9, 2015, p. 1302-1305

Manuscript received: 8.05.2019 